\title{
Theoretical Study of the Function of the IP3 Receptor/BK Channel Complex in a Single Neuron
}

\section{Estudio Teórico de la Función del Complejo Receptor-IP3/Canales BK en Neurona Única}

\section{E. Pérez-Bonilla; M. Reyes-Monreal; J. Quintero-Pérez; M. F. Pérez-Escalera; A. Reyes-Lazalde}

Benemérita Universidad Autónoma de Puebla

\begin{abstract}
Large conductance calcium-activated potassium (BK) channels carry out many functions in the central nervous system. These channels open in response to increased cytosolic calcium $\left(\left[\mathrm{Ca}^{2+}\right]_{\text {cyt }}\right)$ concentration. The influx of calcium ions to the cytosol can occur through voltage-gated calcium channels (VGCCs) on the plasma membrane and/ or through $\mathrm{IP}_{3}$ receptors ( $\mathrm{IP}_{3}-\mathrm{Rs}$ ) and ryanodine receptors (RyRs) on the endoplasmic reticulum membrane. The $\mathrm{BK}$ channel/IP $-\mathrm{R} / \mathrm{RyR}$ interaction has been widely reported in smooth muscle but scarcely investigated in relation to neurons. The aim of this study was to theoretically explore the function of the $\mathrm{BK} / \mathrm{IP}_{3}-\mathrm{R}$ complex by means of a computational model of a neuron that replicates the interaction between the release of $\mathrm{Ca}^{2+}$ from the endoplasmic reticulum (through $\mathrm{IP}_{3}$-Rs) and the opening of the BK channels. The mathematical models are based on the Hodgkin-Huxley formalism and the Goldbeter model. These models were implemented on Visual Basic ${ }^{\circledR}$ and differential equations were solved numerically. Distinct conditions were contemplated for BK conductance and the efflux of endoplasmic $\mathrm{Ca}^{2+}$ to the cytosol. An abrupt rise in $\left[\mathrm{Ca}^{2+}\right]_{\text {cyt }}(\geq 5 \mu \mathrm{M})$ and short duration (spark) was found to activate BK channels and either pause or stop the action potential train.
\end{abstract}

KEYwORDS: BK channels; IP3 receptor; $\mathrm{Ca}^{2+}$ microdomains; Single-neuron simulations; SERCA pump 


\section{RESUMEN}

Los canales de potasio activados por calcio de gran conductancia (canales BK) cumplen múltiples funciones en el sistema nervioso central. Estos canales se abren en respuesta al incremento de la concentración de calcio citosólico $\left(\left[\mathrm{Ca}^{2+}\right]_{\mathrm{cyt}}\right)$. La entrada de $\mathrm{Ca}^{2+}$ puede ocurrir a través de canales de calcio dependientes de voltaje (VGCCs) localizados en la membrana plasmática y por eflujo de $\mathrm{Ca}^{2+}$ del retículo endoplásmico (ER) causado por 1,4,5-Trifosfato (IP ${ }_{3}$ ) o rianodina (RyR). La interacción $\mathrm{BK} / \mathrm{IP}_{3} / \mathrm{RyR}$ ha sido ampliamente estudiada en músculo liso, pero escasamente en neuronas. El objetivo de este estudio fue explorar teóricamente la función del complejo $\mathrm{BK}_{\mathrm{IP}}$ - $\mathrm{R}$ mediante un modelo computacional de una neurona que replica la interacción entre la liberación de $\mathrm{Ca}^{2+}$ del retículo endoplásmico (a través de $\mathrm{IP}_{3}$-Rs) y la apertura de los canales BK. Los modelos matemáticos se basan en el formalismo de Hodgkin-Huxley y el modelo de Goldbeter. Estos modelos fueron implementados en Visual Basic ${ }^{\circledR}$ y las ecuaciones diferenciales fueron resueltas por métodos numéricos. Se contemplaron distintas condiciones para la conductancia del canal BK y la salida de $\mathrm{Ca}^{2+}$ endoplásmico al citosol. Los resultados muestran que un incremento abrupto de [Ca ${ }^{2+}$ ] cyt $(\geq 5 \mu \mathrm{M})$ y de corta duración (spark) activa los canales BK y producen una pausa o detiene el tren de potenciales de acción.

PALABRAS CLAVE: BK channels; IP3 receptor; $\mathrm{Ca}^{2+}$ microdomains; Single-neuron simulations; SERCA pump

\section{Corresponding author}

TO: Arturo Reyes Lazalde

INSTITUTION: Benemérita Universidad

Autónoma de Puebla

ADDRESS: 15 Poniente \#1102-A, Col. Álvaro Obregón,

C. P. 74260, Atlixco, Puebla, México

E-MAIL: arturoreyeslazalde@gmail.com

\section{Received:}

17 October 2020

Accepted:

6 January 2021 


\section{INTRODUCTION}

In neurons, maintaining the homeostasis of calcium ions $\left(\mathrm{Ca}^{2+}\right)$ is essential for proper signaling and function. The endoplasmic reticulum (ER) serves as the main $\mathrm{Ca}^{2+}$ storage organelle in neurons and has mechanisms of influx and efflux of this ion. Such mechanisms, located on the ER membrane, help to regulate the cytosolic concentration of $\mathrm{Ca}^{2+}$. The influx mechanism is based on $\mathrm{Ca}^{2+}$ pumps, while the most important efflux mechanisms are triggered by inositol 1,4,5-trisphosphate $\left(\mathrm{IP}_{3}\right)$ receptors $\left(\mathrm{IP}_{3}-\mathrm{Rs}\right)$ and ryanodine receptors (RyRs). The rise in the level of $\mathrm{Ca}^{2+}$ in the cytosol active the large-conductance calcium-activated potassium channels, or big potassium (BK) channels.

Various mathematical models have been developed to replicate the release of $\mathrm{Ca}^{2+}$ from the ER and the pattern of the cytosolic $\mathrm{Ca}^{2+}$ concentration, hereafter denominated $\left[\mathrm{Ca}^{2+}\right]_{\mathrm{cyt}}$. However, they have not been associated with BK channels in order to research their joint function at the somatic level, explore the mechanisms involved, and determine the importance they have in neuronal activity. A theoretical study was carried out on the functional coupling of $\mathrm{IP}_{3}$-Rs to $\mathrm{BK}$ channels in a single neuron and the effects produced. An interaction is proposed in the soma of the neuron in a microdomain formed by the proximity of the BK channels of the plasma membrane to the calcium efflux channels triggered by the $\mathrm{IP}_{3}$-Rs located on the ER membrane.

\section{BK channels}

Large conductance (BK) channels are part of the family of calcium-activated potassium channels. They are distinguished from other calcium-activated potassium channels (small and intermediate conductance) by their capacity to couple $\left[\mathrm{Ca}^{2+}\right]_{\mathrm{cyt}}$ and sense the membrane potential variations. BK channels are widespread in the brain, being found in the cerebral cortices, cerebellar cortex, hippocampus, olfactory bulb, vestibular nuclei, basal ganglia, hypothalamus, and thalamus ${ }^{[1]}$.
Calcium-activated potassium channels exist in diverse cell types ${ }^{[2]}$. On neurons, BK channels are present in dendrites, soma, axons, and synaptic terminals ${ }^{[1]}$. Upon analyzing aplysia nerve cells, Meech ${ }^{[3]}$ identified for the first time a potassium current activated by a rise in the level of $\left[\mathrm{Ca}^{2+}\right]_{\mathrm{cyt}}$. After microinjection of calcium, the cell membrane was hyperpolarized and an increase in $\mathrm{Ca}^{2+}$-activated $\mathrm{K}^{+}$conductance $\left(\mathrm{gK}_{\mathrm{Ca}}\right)$ occurred concomitantly ${ }^{[3]}$. Since then, these channels have been investigated to characterize their molecular structure, electrophysiology, and pharmacology ${ }^{[4]}$. According to their single-channel conductance, $\mathrm{K}_{\mathrm{Ca}}$ channels are divided into three main subfamilies: (1) small conductance (SK) (4-14 pS), (2) intermediate conductance (IK) (32-39 pS), and (3) large conductance (BK) (200-300 pS) channels ${ }^{[4]}{ }^{[5]}$.

The BK channels have several distinctive characteristics. (1) They are homotetramers with two regulatory domains containing two high-affinity $\mathrm{Ca}^{2+}$ binding sites. (2) They are voltage and calcium-dependent, requiring both membrane depolarization and calcium for their activation. $\mathrm{Ca}^{2+}$ binding and voltage sensor activation act almost independently to enhance channel opening ${ }^{[6]}$. BK channels can open in the absence of calcium but are more sensitive to calcium at depolarizing voltage steps ${ }^{[2]}$. Hence, their sensitivity to calcium is strongly dependent on the membrane potential. The dissociation constant (Kd) for calcium is in the micromolar range at $-60 \mathrm{mV}$ and in the nanomolar range at +20 to $+40 \mathrm{mV}^{[7]}$. (3) BK channels are fast activating (on the order of $1 \mathrm{~ms}$ or less) compared to IK and SK channels, which have a slow activation time (lasting hundreds of milliseconds or over a second, respectively) ${ }^{[8]}$.

BK channels have various functions in the central nervous system. At the soma of many neuronal cells, they control the speed of action potential repolarization and mediate the rapidity of afterhyperpolarization. Therefore, they can influence spike frequency adaptation ${ }^{[9][10]}$. They are often physically associated 
with voltage-gated calcium channels (VGCCs), thus forming microdomains with them ${ }^{[11]}{ }^{[12]}$. Due to their presence in nerve terminals and their co-assembly with VGCCs at active zones, BK channels are particularly suitable for regulating the release of neurotransmitters, increase the duration of PA, prevent backpropagation in dendrites, and produce a decrease in firing frequency [9] [13] [14].

The concentration of free and bound $\left[\mathrm{Ca}^{2+}\right]_{\text {cyt }}$ is reported to be approximately $100 \mathrm{nM}$ and $10 \mu \mathrm{M}$, respectively ${ }^{[15]}$. While a localized increase in $\left[\mathrm{Ca}^{2+}\right]_{\mathrm{cyt}}$ has been evidenced in some studies, others show spatio-temporal calcium signaling restricted to nano and microdomains in neurons ${ }^{[16]}$ and smooth muscle ${ }^{[17][18]}$. In a BK channel-VGCC microdomain, according to Fakler and Adelman ${ }^{[18]}$, the kinetics of $\left[\mathrm{Ca}^{2+}\right]_{\text {cyt }}$ exhibit a localized boost of up to $20 \mu \mathrm{M}$ in neurons. The [ $\left.\mathrm{Ca}^{2+}\right]$ cyt concentration decreases with distance due to the diffusion process and interaction with the chelators (1, 2-bis (o-aminophenoxy)et ha ne-N,N, N', N' tetraacetic acid (BAPTA) and ethylene glycol-bis(b-aminoethyl ether)- N,N,N',N'-tetraacetic acid (EGTA) ${ }^{[18]}$.

\section{Endoplasmic reticulum (ER)}

Because of containing a high concentration of $\mathrm{Ca}^{2+}$ binding proteins, the $\mathrm{ER}$ is the main $\mathrm{Ca}^{2+}$ storage organelle in cells. Indeed, the total amount of $\mathrm{Ca}^{2+}$ may be $>1 \mathrm{mM}$, while the concentration of free $\left[\mathrm{Ca}^{2+}\right]_{\mathrm{ER}}\left(\mathrm{Ca}^{2+}\right.$ in the ER) has been quantified at 100-700 $\mu \mathrm{M}^{[19]}$.

To maintain equilibrium, mechanisms of influx and efflux of $\mathrm{Ca}^{2+}$ are activated on the ER membrane. There are two types of processes related to the efflux of $\mathrm{Ca}^{2+}$ from the ER, being the $\mathrm{Ca}^{2+}$-induced $\mathrm{Ca}^{2+}$ release (CICR) and $\mathrm{IP}_{3}$-induced $\mathrm{Ca}^{2+}$ release (IICR) processes. The $\left[\mathrm{Ca}^{2+}\right]_{\text {cyt }}$ interacts with ryanodine receptors and $\mathrm{IP}_{3}$ receptors (RyRs, $\mathrm{IP}_{3}$-Rs) in the former and $\mathrm{IP}_{3}$ with its receptors $\left(\mathrm{IP}_{3}-\mathrm{Rs}\right)$ in the latter, in both cases to release $\mathrm{Ca}^{2+}$ from the ER ${ }^{[20]}$. On the other hand, $\mathrm{Ca}^{2+}$ is recaptured into the ER by the activity of smooth endoplas- mic reticulum $\mathrm{Ca}^{2+}$-ATP ${ }_{\text {ase }}$ (SERCA) pumps ${ }^{\text {[21] }}$. Thus, a low concentration of $\left[\mathrm{Ca}^{2+}\right]_{\mathrm{cyt}}(50-100 \mathrm{nM})$ is maintained by the coordinated action of the inflow of $\mathrm{Ca}^{2+}$ to the ER through pumps on the ER membrane, and the efflux of $\mathrm{Ca}^{2+}$ from the cytosol to the extracellular space through pumps (PMCA) on the plasma membrane ${ }^{[22]}$.

\section{BK channel - IP ${ }_{3}$ receptor interaction}

The BK channel/ $\mathrm{IP}_{3}-\mathrm{R}$ microdomain has received less attention, and its role is controversial. $\mathrm{IP}_{3}$-Rs are localized in the ER membrane and the BK channels in the plasma membrane. The $\mathrm{BK}$ channels and $\mathrm{IP}_{3}$ receptors are very close to one another ${ }^{[23]}$. The ER membrane is believed to be initially generated as part of the nuclear envelope, which then expands and morphs into a complex reticulum that can extend to distant cellular compartments such as the axons, dendrites, and dendritic spines of neurons, but with a similar morphology and there is closeness between the ER membrane and the

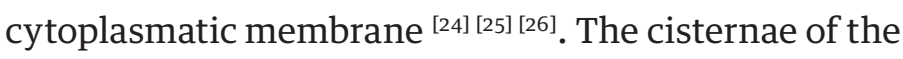
ER are classified in accordance with their proximity to the plasma membrane. Type I is the farthest from the plasma membrane, while type II and III are nearer, frequently following its profile ${ }^{[26]}$.

Pan et al., reported the interaction between BK channels and $\mathrm{IP}_{3}$-Rs in human embryonic kidney cells (HEK293) ${ }^{[27]}$. Neuropeptide galanin activates galanin receptors (GalR2s), and $\mathrm{IP}_{3}$-Rs are activated through the protein kinase $\mathrm{G}$ pathway. The increase in $\left[\mathrm{Ca}^{2+}\right]_{\mathrm{cyt}}$ is due to $\mathrm{Ca}^{2+}$ efflux from the ER through $\mathrm{IP}_{3}-\mathrm{Rs}$. The authors demonstrated that the rise in the level of $\left[\mathrm{Ca}^{2+}\right]_{\mathrm{cyt}}$ comes from the ER but did not quantify this change.

In arterial smooth muscle cells, relaxation and contraction are regulated by calcium released from the sarcoplasmic reticulum. The flow of calcium from the ER to the cytosol (induced by $\mathrm{IP}_{3}$ and ryanodine) activates the BK channels, thus facilitating a negative feedback mechanism in opposition to vasoconstric- 
tion ${ }^{[17]}$. There is evidence of the proximity of BK channels and calcium release sites. This is further supported by co-immunoprecipitation experiments ${ }^{[28]}$. As a consequence, such channels would be exposed to a high calcium concentration $(>10 \mu \mathrm{M}$, in the order of 1-100 $\mu \mathrm{M})$.

In neurons, Irie and Trussell ${ }^{[23]}$ described a nanodomain between RyRs on the ER membrane and plasma membrane VGCCs (voltage-gated $\mathrm{Ca}^{2+}$ channels), and another one between RyRs and BK channels in the soma of cartwheel inhibitory interneurons of the dorsal cochlear nucleus. Through the VGCC-RyR interaction, the latter receptors trigger the release of $\mathrm{Ca}^{2+}$. The internal increase in calcium acts on plasma membrane BK channels to control action potential activity and shape the burst. The interaction of the nanodomains and the $\mathrm{Ca}^{2+}$ transients must be very rapid (in a millisecond timescale), and thus arise only tens of nanometers from the plasma membrane ${ }^{[23]}$.

$\mathrm{IP}_{3}$ is highly mobile in the cytosol. It is synthesized in the plasma membrane and diffuses into the cell where it encounters its specific receptors $\left(\mathrm{IP}_{3}-\mathrm{Rs}\right)$ on the ER ${ }^{[29]}$. In neocortical pyramidal neurons, $\mathrm{IP}_{3}$ produces calcium waves via activation of metabotropic glutamate receptors. When measured with non-buffering low-affinity $\mathrm{Ca}^{2+}$ indicators, such waves have a peak amplitude of over $5 \mu \mathrm{M}^{\left[{ }^{[0]}\right.}$ and propagate with a velocity of $\sim 100 \mu \mathrm{m} / \mathrm{s}{ }^{[31]}$. According to Ross ${ }^{[31]}$, the release of $\mathrm{Ca}^{2+}$ from ER has been less studied because it is not associated with specific changes in the membrane potential. As can be seen in this work, the impact of the release of $\mathrm{Ca}^{2+}$ from ER on the membrane potential was researched indirectly through the BK channels.

The importance of the interaction between BK channels and voltage-gated calcium channels has been demonstrated in the release of neurotransmitters, where they play a regulatory role that prevents excito- toxicity ${ }^{[32]}$; in the smooth muscle of blood vessels, where it regulates blood pressure and plays an important role in preventing hypertension ${ }^{[33]}$. In these cases, the prevention mechanism is a negative feedback system. The experimental study is facilitated because both channels are found on the same membrane, and voltage clamping and transfections can be performed to combine different types of VGCC channels with the BK channel, etc. On the other hand, the experimental study of the $\mathrm{BK} / \mathrm{IP} \mathrm{P}_{3}-\mathrm{R}$ complex is more difficult, the channels are in different membranes and consequently, voltage clamping cannot be performed. This justifies a theoretical study of the $\mathrm{BK} / \mathrm{IP}_{3}-\mathrm{R}$. It is unknown whether, at a somatic level in neurons, the $\mathrm{BK} / \mathrm{IP}_{3}-\mathrm{R}$ interaction is present as a protective mechanism. Based on the reported studies, the coexistence of BK and $\mathrm{IP}_{3}-\mathrm{R}$ channels at the somatic level is known ${ }^{[23]}$ and of the proximity of the cell membrane and the endoplasmic reticulum and contact sites between these structures ${ }^{[24]}$, necessary conditions for the presence of BK/ $\mathrm{IP}_{3}-\mathrm{R}$. The proposed hypothesis is that: in neurons, at the somatic level, there is a $\mathrm{BK} / \mathrm{IP}_{3}-\mathrm{R}$ interaction. If this is so, what would its role be in neuronal activity? What would be the mechanisms involved? It is not known whether an abrupt and short-term outflow of $\mathrm{Ca}^{2+}$ could activate BK channels in the neuron's soma; it is also not known whether there is a commitment between the number of BK channels present in the membrane and the response of the neuron to $\left[\mathrm{Ca}^{2+}\right]_{\mathrm{cy}}$.

\section{Modeling of $\mathrm{Ca}^{2+}$ release from $\mathrm{IP}_{3} \mathbf{R}$}

Based on detailed knowledge of the timescales of $\mathrm{Ca}^{2+}$ release from the ER and the pattern of $\left[\mathrm{Ca}^{2+}\right]_{\mathrm{cyt}}$ concentration, mathematical models have been developed to replicate variations in $\left[\mathrm{Ca}^{2+}\right]_{\mathrm{cyt}}$. The resulting models are of three types. Firstly, there are models for the release of $\mathrm{Ca}^{2+}$ (with simplified dynamics) from the ER or the sarcoplasmic reticulum through the $\mathrm{IP}_{3}-\mathrm{R}$. Such early models are purely phenomenological [34] [35]. Secondly, some models incorporate molecular details of the interaction of $\mathrm{IP}_{3}$ and $\mathrm{Ca}^{2+}$ with the $\mathrm{IP}_{3}-\mathrm{R}$, consid- 
ering microscopic kinetics and a detailed gating scheme for the receptor [36] [37] [38] [39] [40] [41]. Thirdly, some models (e.g., the one created by Blackwell and Kotaleski, in ${ }^{[39]}$ ) also incorporate second messengers within the biochemical reactions that are triggered by metabotropic glutamate receptor (mGluR) activation and lead to $\mathrm{IP}_{3}$ production. Each group of models has different timescales.

The mathematical models are related to the molecular interaction of $\mathrm{IP}_{3}$ with the $\mathrm{IP}_{3}-\mathrm{R}$ and the $\mathrm{Ca}^{2+}-$ activated channel, which are activated sequentially for the release of $\mathrm{Ca}^{2+}$ from the ER. These models have employed different mathematical techniques ${ }^{[40]}$. The current contribution focuses on the interaction of $\left[\mathrm{Ca}^{2+}\right]_{\mathrm{ER}}$ with BK channels. Detailed molecular kinetics of the mechanisms of release of $\mathrm{Ca}^{2+}$ from the ER is not essential for the purpose of this work. The phenomenological model of Goldbeter of such $\mathrm{Ca}^{2+}$ release was herein found to be sufficiently accurate and appropriate in its timescale and was combined with the phenomenological model of Hodgkin and Huxley. The latter formulation describes the electrical activity of neurons ${ }^{[41]}$. Based on the aforementioned models, the present study theoretically explored the function of a $\mathrm{BK} / \mathrm{IP}_{3}-\mathrm{R}$ microdomain.

\section{MATERIALS AND METHODS}

In the development of a new model, consideration was given to the spatial structure of the soma and some key concepts related to the kinetics of $\mathrm{Ca}^{2+}$. The increase in $\mathrm{Ca}^{2+}$ is located in the microdomain ${ }^{[16]}$ formed mainly by the following factors ${ }^{[28]}$ : the $\mathrm{BK}$ channels on the soma membrane ${ }^{[1]}{ }^{[44]}$ and the $\mathrm{Ca}^{2+}$ and $\mathrm{IP}_{3}$-R-sensitive channels on the ER membrane ${ }^{[42]}$. The two membranes are very close to one another ${ }^{[26]}$. There is evidence from electron microscopy, with 3D reconstructions, of the proximity of the plasmatic membrane with the ER membrane and of numerous contact sites between these structures, mainly in the neuron soma ${ }^{[24]}$.

\section{The Hodgkin and Huxley formalism and the BK model}

The electrical activity of the neuron was reproduced with the Hodgkin and Huxley formalism (H-H model), consisting of an equation that represents the membrane potential (Equation 1) and others that define channel gating variables (Equations 2-5) ${ }^{[45][46]}$.

$$
\begin{aligned}
& C_{m} \frac{d V}{d t}=-\overline{\mathrm{g}}_{N a} m^{3} h\left(V-E_{N a}\right)-\overline{\mathrm{g}} n^{4}\left(V-E_{K}\right)- \\
& \overline{\mathrm{g}}_{L}\left(V-E_{L}\right)-\overline{\mathrm{g}}_{B K} q\left(V-E_{K}\right) \\
& \frac{d m}{d t}=\alpha_{m}(V)(1-m)-\beta_{m}(V) m \\
& \frac{d h}{d t}=\alpha_{h}(V)(1-h)-\beta_{h}(V) h \\
& \frac{d n}{d t}=\alpha_{n}(V)(1-n)-\beta_{n}(V) n \\
& \frac{d q}{d t}=\alpha_{q}(V)(1-q)-\beta_{q}(V) q
\end{aligned}
$$

Where $\alpha_{\mathrm{m}}(\mathrm{V}), \beta_{\mathrm{m}}(\mathrm{V}), \alpha_{\mathrm{h}}(\mathrm{V}), \beta_{\mathrm{h}}(\mathrm{V}), \alpha_{\mathrm{n}}(\mathrm{V}), \beta_{\mathrm{n}}(\mathrm{V}), \alpha_{\mathrm{q}}(\mathrm{V})$, and $\beta_{\mathrm{q}}(\mathrm{V})$ are activation and inactivation gatin variables and are defined according to the following empir-

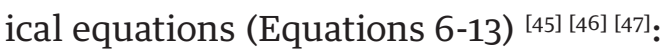

$$
\begin{aligned}
& \alpha_{m}(V)=\frac{-0.1(V+40)}{1-\exp \left(\frac{-(V+40)}{10}\right)} \\
& \beta_{m}(V)=4 \exp \left(\frac{-(V+65)}{18}\right) \\
& \alpha_{h}(V)=0.07 \exp \left(\frac{-(V+65)}{20}\right) \\
& \beta_{h}(V)=\frac{1}{1+\exp \left(\frac{-(V+35)}{10}\right)}
\end{aligned}
$$




$$
\begin{aligned}
& \alpha_{n}(V)=\frac{0.01(V+55)}{1-\exp \left(\frac{-(V+55}{10}\right)} \\
& \beta_{n}(V)=0.125 \exp \left(\frac{-(V+65)}{80}\right) \\
& \alpha_{q}(V)=e^{\left(\frac{V}{27}\right)} 0.005 \frac{{ }^{200-\left[C a^{2+}\right]_{c y t}}}{\exp \left(\frac{200-\left[C a^{2+}\right]_{c y t}}{20}\right)-1}
\end{aligned}
$$$$
\beta_{q}(V)=0.0004 \text { to } 0.002
$$

\begin{tabular}{|c|c|c|c|}
\hline Symbol & Values & Units & Definitions \\
\hline V & $-90^{*}$ & $\mathrm{mV}$ & $\begin{array}{c}\text { Membrane } \\
\text { potential }\end{array}$ \\
\hline $\mathrm{C}_{\mathrm{m}}$ & 1 & $\mu \mathrm{F} \cdot \mathrm{cm}^{-2}$ & $\begin{array}{l}\text { Membrane } \\
\text { capacitance }\end{array}$ \\
\hline $\mathrm{E}_{\mathrm{Na}}$ & 50 & \multirow{3}{*}{$\mathrm{mV}$} & \multirow{3}{*}{$\begin{array}{l}\text { Equilibrium } \\
\text { potential for } \\
\mathrm{Na}^{+}, \\
\mathrm{K}^{+} \text {, and leak }\end{array}$} \\
\hline $\mathrm{E}_{\mathrm{K}}$ & -77 & & \\
\hline $\mathrm{E}_{\mathrm{L}}$ & -22 & & \\
\hline$\overline{\mathrm{g}}_{\mathrm{Na}}$ & 120 & \multirow{4}{*}{$\mathrm{mS} \cdot \mathrm{cm}^{-2}$} & \multirow{4}{*}{$\begin{array}{l}\text { Maximum } \\
\text { conductance } \\
\text { for } \mathrm{Na}^{+}, \mathrm{K}^{+}, \\
\text {leak and } \mathrm{BK}\end{array}$} \\
\hline$\overline{\mathrm{g}}_{\mathrm{K}}$ & 20 & & \\
\hline$\overline{\mathrm{g}}_{\mathrm{L}}$ & 0.3 & & \\
\hline$\overline{\mathrm{g}}_{\mathrm{BK}}$ & $* *$ & & \\
\hline$\left[\mathrm{Ca}^{2+}\right]_{\mathrm{cyt}}$ & $* * *$ & $\mu \mathrm{M}$ & $\begin{array}{l}\text { Calcium ions } \\
\text { in the cytosol }\end{array}$ \\
\hline
\end{tabular}

TABLE 1. The parameters of the $\mathrm{H}-\mathrm{H}$ model (from ${ }^{[45]}$ ).

\section{Goldbeter Model}

The mathematical model of Goldbeter (1990) was found to be adequate ${ }^{[32]}$ because the time involved in the BK channel is on a millisecond scale ${ }^{[48][49][50]}$ and our interest is in the $\left[\mathrm{Ca}^{2+}\right]_{\text {cyt }}$ concentration and not in the details of the interaction of $\mathrm{IP}_{3}$ with $\mathrm{IP}_{3}-\mathrm{R}$. Hence, two different mechanisms were contemplated for the release of $\mathrm{Ca}^{2+}$ from the ER, one sensitive to $\mathrm{IP}_{3}$ (the IICR) ${ }^{[38]}$, and the other to $\mathrm{Ca}^{2+}$ (the CICR) ${ }^{[48]}$.

Dupont and Goldbeter developed another model with a single compartment. In a single group, considering the existence of the same two types of channels (one sensitive to $\mathrm{Ca}^{2+}$ and the other to $\mathrm{IP}_{3}$ ), no oscillations occur unless the contribution of the IICR is insignificant compared to that of the CICR ${ }^{[49]}$. Oscillations in $\left[\mathrm{Ca}^{2+}\right]_{\mathrm{cyt}}$ are similar in the one- and two-compartment models ${ }^{[49]}$. The latter was employed in the present study since it does not require such an extreme decrease in the contribution of the IICR as needed in the one-compartment model.

The model has two variables, free $\left[\mathrm{Ca}^{2+}\right]_{\mathrm{cyt}}(\mathrm{Z})$ and free $\left[\mathrm{Ca}^{2+}\right]_{\mathrm{ER}}$ concentrations, modulated through the $\mathrm{Ca}^{2+}$ -sensitive mechanism (Y). The system is governed by the two kinetic equations ${ }^{[32]}$ :

$$
\begin{aligned}
& \frac{d Z}{d t}=V_{0}+V_{1} * \beta-V_{2}+V_{3}+K_{f} Y-k Z \\
& \frac{d Y}{d t}=V_{2}-V_{3}-k_{f} Y
\end{aligned}
$$

Where $\mathrm{V}_{0}$ is related to the flow of $\mathrm{Ca}^{2+}$ into the cell, $\mathrm{k}$ to its flow out of the cell, $\mathrm{V}_{1}$ to its flow into the cytosol from the $\mathrm{IP}_{3}$-sensitive mechanism, $\beta$ to the saturation function of $\mathrm{IP}_{3}$-Rs (cooperative nature), and $\mathrm{K}_{\mathrm{f}}$ to the leaky transport of $\mathrm{Y}$ into $\mathrm{Z}$. Finally, $\mathrm{V}_{2}$ expresses the rate of the SERCA pump and $\mathrm{V}_{3}$ the rate of transport of $\mathrm{Ca}^{2+}$ released from the $\mathrm{IP}_{3}$-sensitive mechanism into the cytosol.

$$
\begin{aligned}
& V_{2}=V_{M 2} \frac{Z^{n_{H} \text { Hill }}}{K_{2}^{n_{H i l l}}+Z^{n_{H i l l}}} \\
& V_{3}=V_{M 3} \frac{Y^{m_{\text {Hill }}}}{K_{R}^{m_{\text {Hill }}+Y^{m_{\text {Hill }}}} \frac{Z^{p_{\text {Hill }}}}{K_{A}^{p_{\text {Hill }}+Z^{p_{\text {Hill }}}}}}
\end{aligned}
$$

$\mathrm{V}_{\mathrm{M} 2}$ denotes the maximum rate at which $\mathrm{Ca}^{2+}$ is pumped into the ER store and $\mathrm{V}_{\mathrm{M}_{3}}$ the $\mathrm{IP}_{3}$-sensitive release of ions from this location. The complementary processes are represented by Hill functions. Thus, $\mathrm{n}_{\text {Hill }}$ and $\mathrm{m}_{\text {Hill }}$ depict the cooperativity coefficients, $\mathrm{p}_{\text {Hill }}$ reflects the degree of cooperativity of activation, and the constants $\mathrm{K}_{2}, \mathrm{~K}_{\mathrm{R}}$, and $\mathrm{K}_{\mathrm{A}}$ designate the point at 
which pumping, release, and activation are triggered [49]. Since the ATPase pump (SERCA) binds to two calcium ions per molecule of ATP, its activity is expressed by using Michaelis-Menten kinetics and a value of 2 for the Hill coefficient (Equation 16) ${ }^{[50]}$.

\section{TABLE 2. Parameters of the Goldbeter model ${ }^{[32]}$.}

\begin{tabular}{|c|c|c|c|}
\hline Symbol & Values & Units & Definitions \\
\hline \multicolumn{4}{|c|}{ Rate of transport from $\mathrm{Ca}^{2+}$-sensitive pool into the cytosol } \\
\hline $\mathrm{V}_{3}$ & \multicolumn{3}{|c|}{ flow rate of $\mathrm{Ca}^{2+}$ from the ER to the cytosol } \\
\hline $\mathrm{V}_{\mathrm{M} 3}$ & 500 & $\mu \mathrm{M} / \mathrm{s}$ & maximum $V_{3}$ \\
\hline $\mathrm{K}_{\mathrm{R}}$ & 2 & $\mu \mathrm{M}$ & \multirow{2}{*}{ constants } \\
\hline $\mathrm{K}_{\mathrm{A}}$ & .09 & $\mu \mathrm{M}$ & \\
\hline $\mathrm{k}_{\mathrm{f}}$ & 1 & $1 / \mathrm{s}$ & rate constant $\left(\mathrm{Ca}^{2+}\right.$ leak $)$ \\
\hline \multicolumn{4}{|c|}{$\begin{array}{l}\text { ATP-driven pumping of } \mathrm{Ca}^{2+} \text { from the cytosol } \\
\text { into the } \mathrm{Ca}^{2+} \text {-sensitive pool }\end{array}$} \\
\hline $\mathrm{V}_{2}$ & \multicolumn{3}{|c|}{ pumping rate of $\mathrm{Ca}^{2+}$ into the ER (by SERCA) } \\
\hline $\mathrm{V}_{\mathrm{M} 2}$ & 65 & $\mu \mathrm{M} / \mathrm{s}$ & maximum $\mathrm{V}_{2}$ \\
\hline $\mathrm{K}_{2}$ & 1 & $\mu \mathrm{M}$ & constants \\
\hline \multicolumn{4}{|c|}{ Efflux of $\mathrm{Ca}^{2+}$ out of the cell (PMCA bomb) } \\
\hline K & 10 & $1 / \mathrm{s}$ & rate constant \\
\hline \multicolumn{4}{|c|}{ Hill coefficients } \\
\hline nHill & 2 & \multicolumn{2}{|c|}{ Hill coefficient (SERCA bomb) } \\
\hline mHill & 2 & \multirow{2}{*}{\multicolumn{2}{|c|}{$\begin{array}{l}\text { Hill coefficients } \mathrm{Ca}^{2+} \\
\text { release from } \mathrm{Ca}^{2+} \text {-sensitive poll }\end{array}$}} \\
\hline pHill & 4 & & \\
\hline
\end{tabular}

The system of equations was solved simultaneously by the numerical method with a fourth-order RungeKutta algorithm $(\mathrm{dt}=0.01)$ written on Visual Basic ${ }^{[53]}$ ${ }^{[54]}$. The initial conditions were $\mathrm{V}=-90 \mathrm{mV}$, and $\left[\mathrm{Ca}^{2+}\right]$ ${ }_{\text {cyt }}=0.1 \mu \mathrm{M}$ (value entered in the simulator). The simulator was developed and compiled to use in the Windows ${ }^{\circledR}$ environment.

\section{RESULTS AND DISCUSSION}

The module for inputting data into the simulator (Figure 1) provides an interactive resource for experimental recordings, allowing for access to all the parameters of the Goldbeter model ${ }^{[49]}$. There are three types of variables: those that increase or decrease $\left[\mathrm{Ca}^{2+}\right]_{\mathrm{cyt}}$, as well as the ones related to the degree of cooperativity of the activation process $\left(\mathrm{n}_{\mathrm{Hill}}, \mathrm{m}_{\mathrm{Hill}}\right.$, and $\left.\mathrm{p}_{\text {Hill }}\right)$.
Firstly, the influx of $\mathrm{Ca}^{2+}$ to the cytosol depends on the rate of transport through the $\mathrm{IP}_{3}$-sensitive mechanism $\left(r=V_{1}^{*} \beta\right)$ and the $\mathrm{Ca}^{2+}$-sensitive mechanism $\left(\mathrm{V}_{3}\right)$, the maximum rate of $\mathrm{Ca}^{2+}$ pumping release from the ER store $\left(\mathrm{V}_{\mathrm{M} 3}\right)$, the threshold constants for release and activation ( $\mathrm{K}_{\mathrm{R}}$ and $\mathrm{K}_{\mathrm{A}}$, respectively) (Figures 1 and 5), and the passive leak $\left(\mathrm{k}_{\mathrm{f}}\right)$. Secondly, the efflux of $\mathrm{Ca}^{2+}$ out of the cytosol depends on the outflow of $\mathrm{Ca}^{2+}$ from the cell (k) (due to the PMCA pump), the inflow rate of $\mathrm{Ca}^{2+}$ into the ER from the cytosol, involving the rate and maximum rate of the SERCA pump $\left(\mathrm{V}_{2}\right.$ and $\left.\mathrm{V}_{\mathrm{M} 2}\right)$, and the threshold constant for the latter pumping action $\left(\mathrm{K}_{2}\right)$ (Figures 1 and 7). Thirdly, variables must consider the cooperativity degree of the activation process. The range of values for free $\left[\mathrm{Ca}^{2+}\right]_{\text {cyt }}$ is 0.05 to 0.1 , and that for free $\left[\mathrm{Ca}^{2+}\right]_{\mathrm{ER}}$ is 100 to $700 \mu \mathrm{M}{ }^{[53]}$.

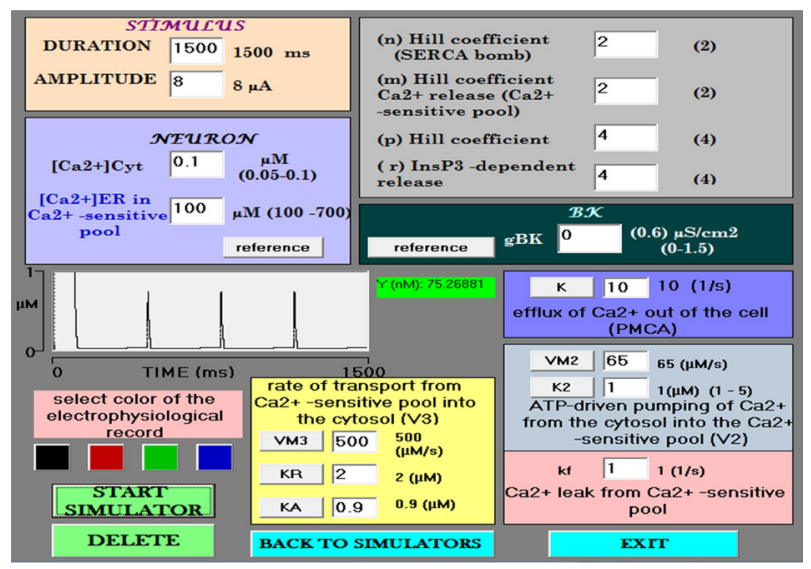

FIGURE 1. Data entry module. The simulator begins at default values for each variable. An enlargement of the small $\mathrm{Ca}^{2+}$ spikes is shown in the center (amplitude = $763 \mathrm{nM}$ ). Under such conditions, the control neuron does not have BK channels $\left(g_{B K}=0\right)$.

When opening the simulator, the default values for each variable appear. The BK channel conductance value starts at zero. The value of free $\left[\mathrm{Ca}^{2+}\right]_{\mathrm{cyt}}$ and free $\left[\mathrm{Ca}^{2+}\right]_{\mathrm{ER}}$ are 0.1 and 100 to $700 \mu \mathrm{M}$, respectively. Each simulation was carried out with the current clamp protocol. To match the timescales of the ion channels in the model with those of the Goldbeter model, a long depolarizing current pulse (1.5 s) is used. Upon start- 
ing a simulation under these conditions, the recorded action potentials correspond to the Hodgkin and Huxley model with only voltage-dependent $\mathrm{Na}^{+}$and $\mathrm{K}^{+}$ channels. The parameters of the Goldbeter model leading to oscillations in $\mathrm{Ca}^{2+}$ begin at the reference values, and immediately after there is an increase in $\left[\mathrm{Ca}^{2+}\right]_{\mathrm{cyt}}$ of $5 \mu \mathrm{M}$ with a duration of $96 \mathrm{~ms}$, (a local $\left[\mathrm{Ca}^{2+}\right]$ cyt transient) followed by calcium spikes of $741 \mathrm{nM}$ (Figure 2).

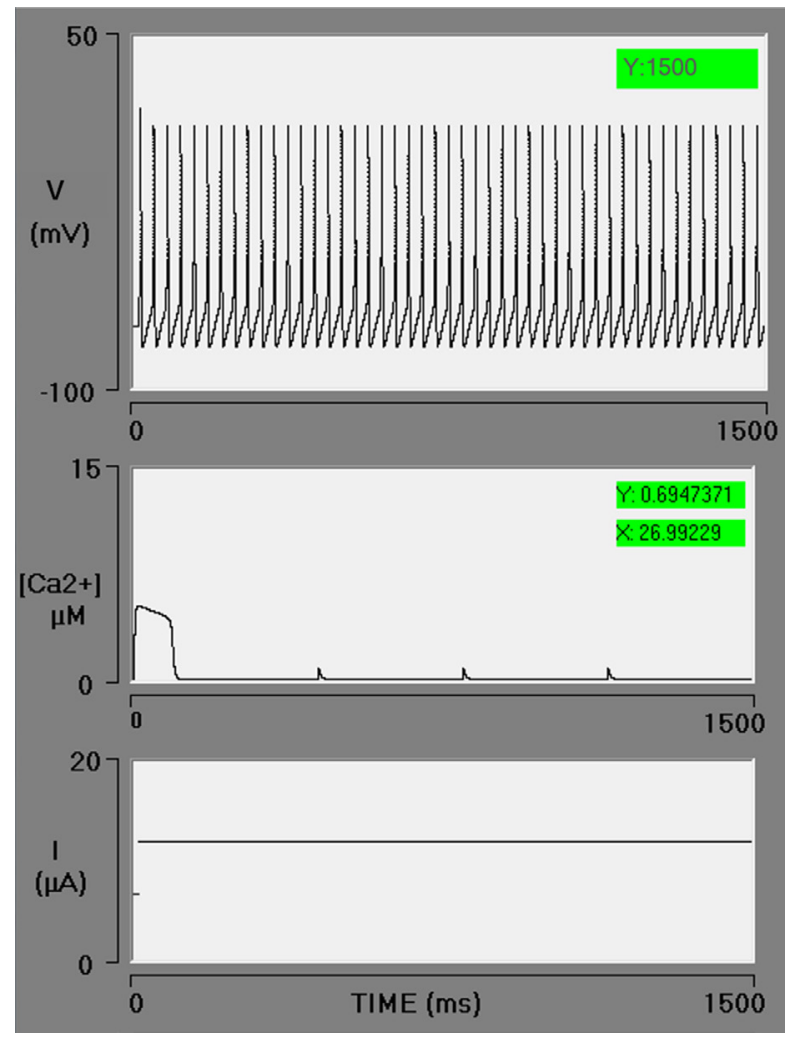

FIGURE 2. Electrophysiology interface simulator with three oscilloscope screens. In the control simulation, the spike train generated by the Hodgkin and Huxley model is displayed on the upper screen. The local cytosolic $\mathrm{Ca}^{2+}$ transient followed by three $\mathrm{Ca}^{2+}$ spikes is exhibited on the middle screen. The stimulus current pulse (with a duration of $1500 \mathrm{~ms}$ ) is illustrated on the bottom screen. In this simulation, the BK conductance is zero.

Khodakhah and Ogden ${ }^{[54]}$ reported that $\mathrm{IP}_{3}$ triggers a release of $\mathrm{Ca}^{2+}$ from the ER with an initial well-defined delay, which decreases as the concentration of $\mathrm{IP}_{3}$ rises (mean, $85 \mathrm{~ms}$ at $10 \mu \mathrm{M} \mathrm{IP}{ }_{3}$ ). In the present study, the simulation is initiated at the moment $\mathrm{Ca}^{2+}$ is released from the ER. Hence, a series of factors are not considered in the model: the interaction of the first messenger with the receptor on the plasma membrane, the cascade of second messengers, the explicit interaction of $\mathrm{IP}_{3}$ and $\mathrm{Ca}^{2+}$ with $\mathrm{IP}_{3}$-Rs, and the corresponding delay in the release of $\mathrm{Ca}^{2+}$. The dynamics of $\mathrm{Ca}^{2+}$ is local. The diffusion and chelation of $\mathrm{Ca}^{2+}$ are not simulated.

Diverse physiological processes (including pathological phenomena) are modulated by the generation and propagation of $\left[\mathrm{Ca}^{2+}\right]_{\text {cyt }}$ signals. The release of $\mathrm{Ca}^{2+}$ from the ER takes place through sparklets, sparks, blink, scintilla, puffs, and other forms ${ }^{[16]}$. Since such elementary events are produced in microdomains, the multiple forms of $\mathrm{Ca}^{2+}$ release confer intracellular $\mathrm{Ca}^{2+}$ signaling with a broad architecture in space, time, and intensity, which in turn underlies signaling efficiency, stability, specificity, and diversity ${ }^{[55]}$. The calcium buffers are instrumental in achieving temporal, spatial, and functional compartmentalization under these conditions, creating steep gradients in a close proximity of channels, until reaching an internal calcium concentration on the order of tens of micromoles ${ }^{[56]}$. The local $\left[\mathrm{Ca}^{2+}\right]_{\mathrm{cyt}}$ transient in this simulation corresponds to a $\mathrm{Ca}^{2+}$ spark, characterized by Cheng and Lederer as having an approximate amplitude of $5 \mu \mathrm{M}$ and a duration of 35 milliseconds in a space of $30 \mathrm{~nm}{ }^{[55]}$. Under the current conditions, the duration of the spark is three times longer and a space of 90-100 $\mathrm{nm}$ would be expected. The activation of BK channels by spark coming from the ER has been described in smooth muscle ${ }^{[17]}$ but not in neuronal cell bodies. The microdomains of $\mathrm{Ca}^{2+}$ consist of very small spaces $(\mathrm{nm})$ between structures (e.g., voltage-gated $\mathrm{Ca}^{2+}$ channels and $\mathrm{BK}$ channels or $\mathrm{IP}_{3}-\mathrm{Rs}$ ), thus involving very local increases in $\mathrm{Ca}^{2+}{ }^{[57]}$. Microdomains between BK channels and $\mathrm{IP}_{3}-$ Rs have been found in different cells, including neurons, with distances of $100 \mathrm{~nm}$ or less ${ }^{[23][59]}$. 
Figure 3 presents four simulations with the following values of $\mathrm{Ca}^{2+}$ in the endoplasmic reticulum pool: 100, 300,600 , and $700 \mu \mathrm{M}$. As a consequence, there is an increase in amplitude $(5,7,10$, and $11 \mu \mathrm{M})$ and duration $(96,235,389$, and $431 \mathrm{~ms})$, respectively, of $\left[\mathrm{Ca}^{2+}\right]_{\mathrm{cyt}}$.

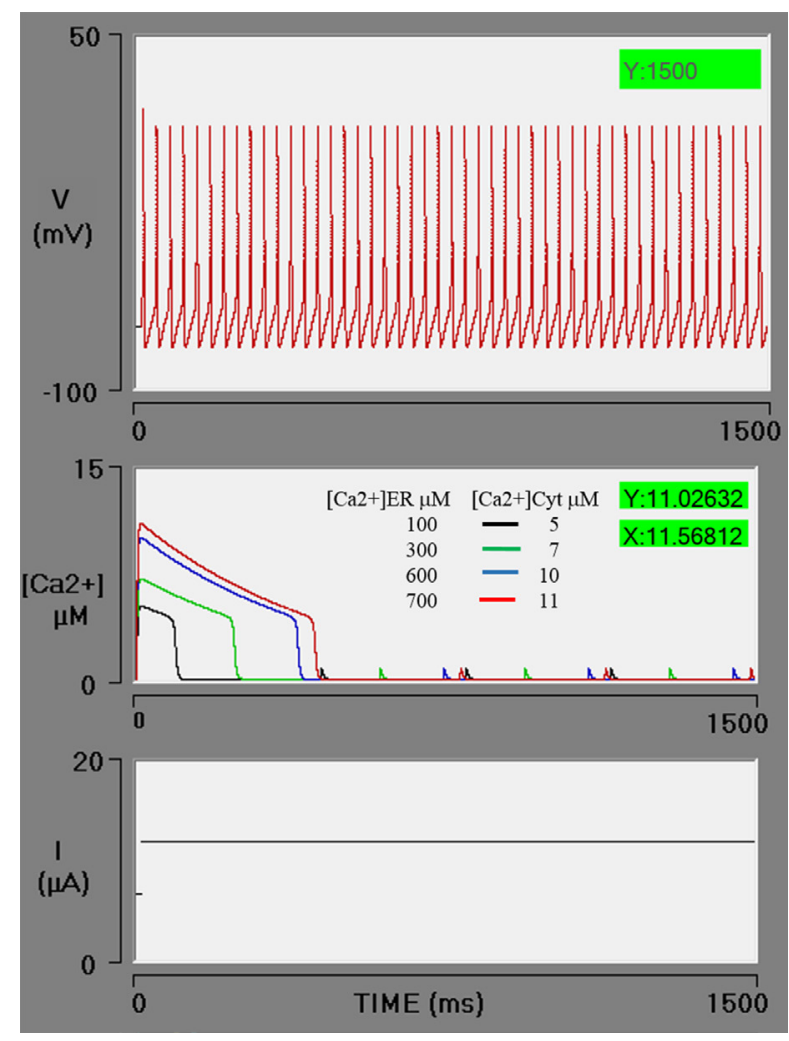

FIGURE 3. Simulations of the effect of an increasing concentration of free $\left[\mathrm{Ca}^{2+}\right]_{\mathrm{ER}}\left(\mathrm{Ca}^{2+}\right.$ in the endoplasmic reticulum) on the level of free $\left[\mathrm{Ca}^{2+}\right]_{\mathrm{cyt}}\left(\mathrm{Ca}^{2+}\right.$ in the cytosol). When the simulations have an $\left[\mathrm{Ca}^{2+}\right]_{\mathrm{ER}}$ value of 100,300, 600 , or $700 \mu \mathrm{M}$ (red box), curves the calcium (sparks) are generated on the middle oscilloscope screen in black, green, blue, and red, with an amplitude or 5, 7, 10 and 11 $\mu \mathrm{M}$, respectively. The PA train is unaffected because the neuron does not have BK channels $\left(\mathrm{g}_{\mathrm{BK}}=0\right)$.

The level of $\left[\mathrm{Ca}^{2+}\right]_{\text {cyt }}$ rises in function of the difference in concentration between free $\left[\mathrm{Ca}^{2+}\right]_{\text {cyt }}$ and the free $\left[\mathrm{Ca}^{2+}\right]_{\mathrm{ER}}$, quantified with the Hodgkin and Huxley formalism (Equation 18).

$$
V_{3}=V_{M 3} R\left[\mathrm{Ca}^{2+}\right]\left(\left[\mathrm{Ca}^{2+}\right]_{E R}-\left[\mathrm{Ca}^{2+}\right]_{c y t}\right)
$$

Where $\mathrm{V}_{3}$ is the $\mathrm{IP}_{3}$-sensitive $\mathrm{Ca}^{2+}$ efflux out of the ER through its membrane and into the cytosol, $\mathrm{V}_{\mathrm{M} 3}$ denotes the maximum rate of such $\mathrm{Ca}^{2+}$ release, and $\mathrm{R}\left[\mathrm{Ca}^{2+}\right]$ depicts the fraction of the calcium channels in the open state, which depends on the $\left[\mathrm{Ca}^{2+}\right]_{\mathrm{cyt}}$ concentration. The function $\mathrm{R}$ has been described by the same sort of mathematical formulations as for the opening of voltage-gated channels, in most cases either by Markov kinetic schemes or by Hodgkin-Huxley-style gating particles. The Goldbeter model uses a simpler approach with a suitable Hill coefficient, $\mathrm{n}_{\text {Hill }}$ (Equation 17) ${ }^{\text {[32] }}$.

\section{Interaction of $\mathrm{IP}_{3}-\mathrm{R} /\left[\mathrm{Ca}^{2+}\right]_{\mathrm{cyt}} / \mathrm{BK}$ channels}

The opening of BK channels is governed by membrane depolarization and a rise in the concentration of $\left[\mathrm{Ca}^{2+}\right]_{\mathrm{cyt}}$. Figure 4 , shows the effect of a $5 \mu \mathrm{M}$ increment in $\left[\mathrm{Ca}^{2+}\right]_{\mathrm{cyt}}$ on the action potential train in the presence of the BK channel. Each simulation has $100 \mu \mathrm{M}$ of $\left[\mathrm{Ca}^{2+}\right]_{\mathrm{ER}}$, with all variables set at the previously described initial values. A range was established for the BK channel conductance values, generally considered as $0.1 \mu \mathrm{S} / \mathrm{cm}^{2}$ in hippocampal neurons and $1.2 \mu \mathrm{S} /$ $\mathrm{cm}^{2}$ in sympathetic ganglion cells, in agreement with the values proposed by Traub and Miles and by Koch and Segev, respectively [46] [60]. Four simulations were carried out with a BK conductance of $0.1,0.6,1.2$, and $1.5 \mu \mathrm{S} / \mathrm{cm}^{2}$, affording the following results (respectively): no effect on the PA train (1500 ms), braking of the PA train at $1050 \mathrm{~ms}$, fast braking at $83 \mathrm{~ms}$, and braking immediately after the first action potential (values in green boxes in Figure $4 \mathrm{~A}, \mathrm{~B}, \mathrm{C}$, and D). Hence, there was a conductance-dependent effect of the $\left[\mathrm{Ca}^{2+}\right]_{\text {cyt }}$ : the higher the conductance, the greater the effect of the $\left[\mathrm{Ca}^{2+}\right]_{\mathrm{cyt}}$ concentration.

The dependence of the BK channel on the voltage is of an allosteric type. It has been proposed that the increase in $\left[\mathrm{Ca}^{2+}\right]_{\text {cyt }}$ could occur almost simultaneously with a rise in voltage, as long as the calcium source is close, as in the case of the BK/VGCC complex ${ }^{[60]}$. In the present study, a $\mathrm{BK} / \mathrm{IP}_{3}-\mathrm{R}$ complex is assumed. Each stimulus 

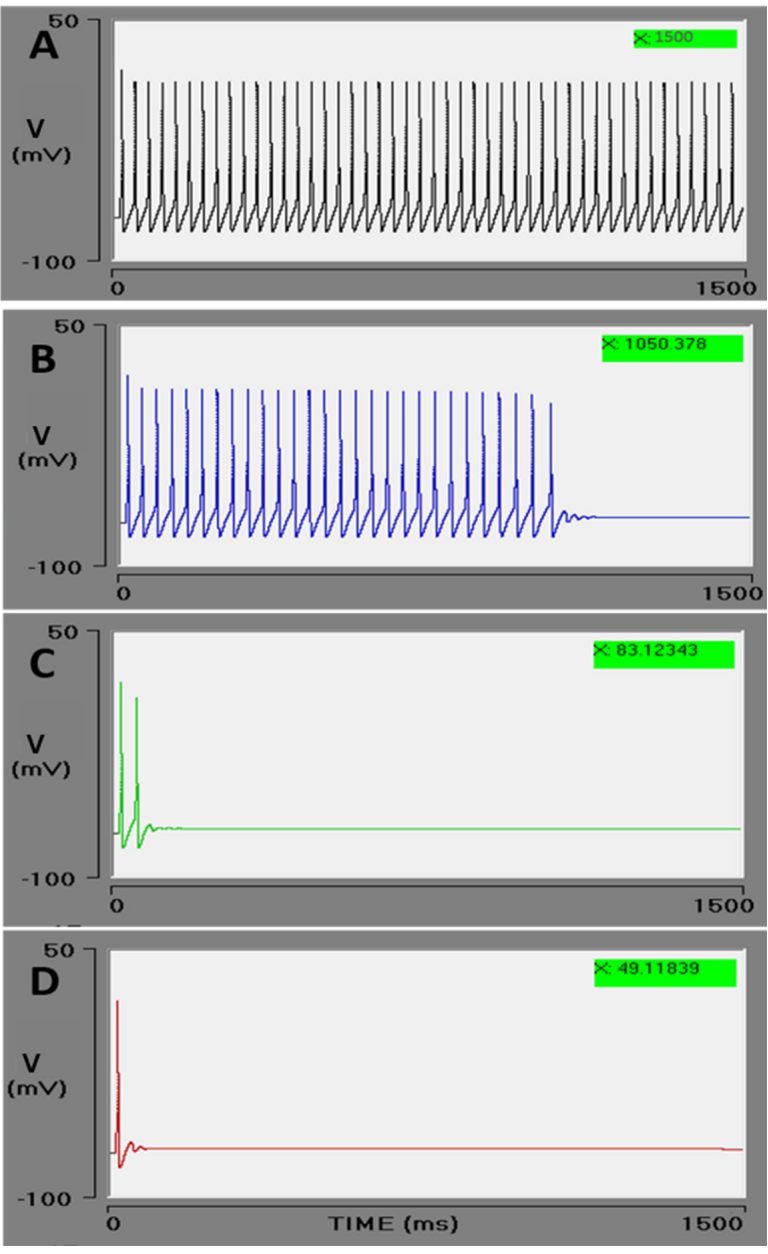

FIGURE 4. Effect of BK conductance on the action potential train. The Goldbeter model produces a $5 \mu \mathrm{M}$ increment in cytosolic calcium. In these conditions, increasingly rapid braking of the action potential train is observed during the interaction of the BK channel with cytosolic calcium. As the conductance of BK channel $\left(\mathrm{g}_{\mathrm{BK}}\right)$ is intensified $\left(\mu \mathrm{S} / \mathrm{cm}^{2}\right)$ : $0.1(\mathrm{~A}), 0.6(\mathrm{~B}), 1.2(\mathrm{C})$, and $1.5(\mathrm{D})$, the PA train durations decreases: 1500, 1050, 83, and 49 (ms), respectively (green boxes). The effect is to stop the action potential train.

(voltage and $\mathrm{Ca}^{2+}$ ) interacts with different parts of the channel ${ }^{[7]}$. The overall conductance of BK channels on the plasma membrane is determined by the conductance of each channel as well as the number and open state probability of these channels (Equation 19) ${ }^{[61]}$.

$$
g_{B K}\left(V,\left[\mathrm{Ca}^{2+}\right]_{c y t}\right)=n_{c} \hat{g} P_{o}\left(V,\left[\mathrm{Ca}^{2+}\right]_{c y t}\right)
$$

Where $\mathrm{n}_{\mathrm{c}}$ denotes the number of ion channels, $\hat{\mathrm{g}}$ represents single-channel conductance (200 to $300 \mathrm{pS}$ ), and $\mathrm{P}_{\mathrm{o}}$ is the open state probability value (o to 1 ).

The activation of BK channels by a rise in $\left[\mathrm{Ca}^{2+}\right]_{\text {cyt }}$ results in a greater open state probability and an enhanced $\mathrm{K}^{+}$efflux. This is the molecular kinetics of channel opening induced by $\mathrm{Ca}^{2+}$ and voltage. The $\left[\mathrm{Ca}^{2+}\right]$ cyt concentration continues to be optimal for a greater channel opening until the saturation point is reached. Consequently, the conductance for each cell depends on the number of channels, and the unit conductance of each one. The results of the simulation indicate that the ease of response of the neuron to the concentration of $\mathrm{Ca}^{2+}$ depends on the number of $\mathrm{BK}$ channels present in its membrane. The higher the conductance, the higher the response to $\mathrm{Ca}^{2+}$ and vice versa.

Subsequently, an evaluation was made of enhancing the rate of the $\mathrm{IP}_{3}$-sensitive release of $\left[\mathrm{Ca}^{2+}\right]_{\mathrm{ER}}$ to the cytosol. The parameters of the neuron were fixed to the default values and the BK conductance set at $0.6 \mu \mathrm{S} / \mathrm{cm}^{2}$ (an intermediate value). By increasing the value of $\mathrm{V}_{\mathrm{M} 3}$ from 500 to 600, a higher level of $\left[\mathrm{Ca}^{2+}\right]_{\mathrm{cyt}}$ is obtained. An abrupt release of $\mathrm{Ca}^{2+}$ from the ER boosts the $\left[\mathrm{Ca}^{2+}\right]_{\text {cyt }}$ from 5 to $6 \mu \mathrm{M}$ (red lines). In the previous simulation (blue lines), corresponding to the effect of $\left[\mathrm{Ca}^{2+}\right]_{\mathrm{cyt}}$ at 5 $\mu \mathrm{M}$, the action potential train was found to brake at 721 ms. When the concentration of $\left[\mathrm{Ca}^{2+}\right]_{\mathrm{cyt}}$ is increased, calcium acts on the BK channel, stopping the action potential train after the second action potential (Figure 5). It is observed that at greater CICR pumping rates, the level of $\left[\mathrm{Ca}^{2+}\right]_{\text {cyt }}$ rises by a calcium-induced calcium release process and/or by the direct action of $\mathrm{IP}_{3}$ on the calcium-IP $-\mathrm{R}$ channel (by Schetter and Smolen in ${ }^{[59]}$ ).

An increment in $\mathrm{V}_{\mathrm{M} 3}$ to $700 \mu \mathrm{M} / \mathrm{s}$ generates a rise in $\left[\mathrm{Ca}^{2+}\right]_{\mathrm{cyt}}$ to $7 \mu \mathrm{M}$. Under these conditions, the neuron stops firing immediately after the first action potential (Figure 6). Although the model of Goldbeter contemplates the action of $\mathrm{IP}_{3}$ on $\mathrm{IP}_{3}-\mathrm{R}$ and offers a good 


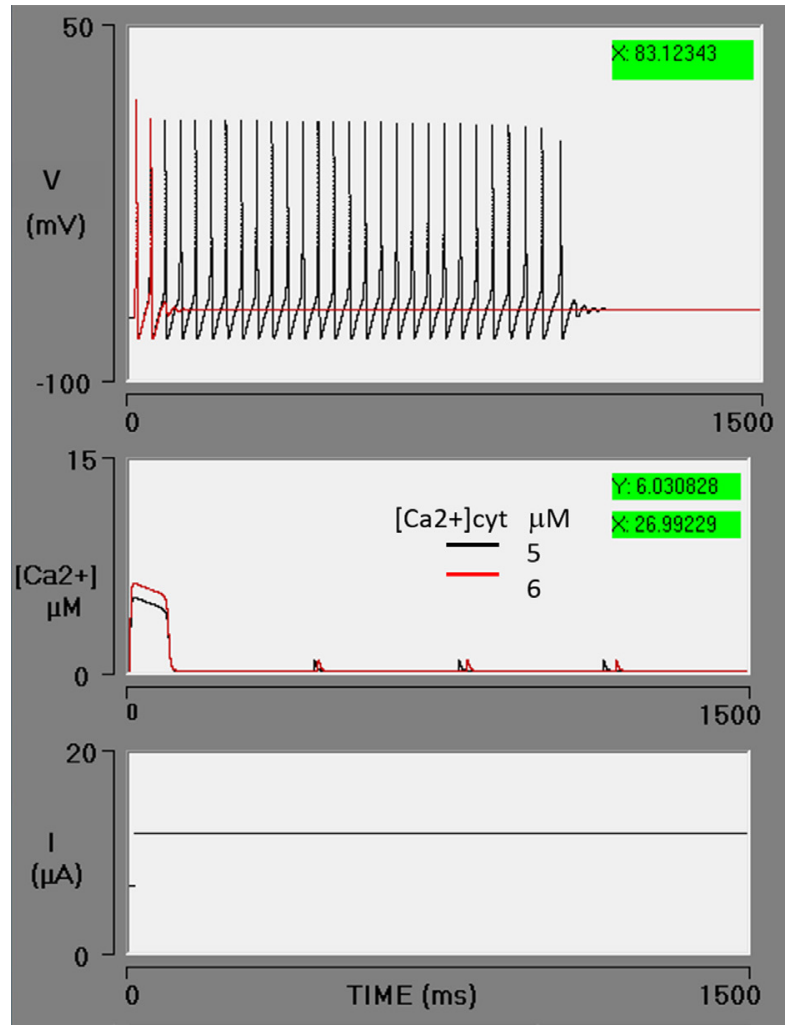

FIGURE 5. Effect of an enhanced $\mathrm{Ca}^{2+}$ efflux from the endoplasmic reticulum to the cytosol. An increment in $\mathrm{V}_{\mathrm{M} 3}$ from 500 to $600 \mu \mathrm{M} / \mathrm{s}$ causes a greater outflow of $\mathrm{Ca}^{2+}$ from the ER to the cytosol, leading to a rise in the cytosolic $\mathrm{Ca}^{2+}$ concentration from 5 to $6 \mu \mathrm{M}$. With an intensified activation of BK channels, the action potential train stops after the second firing. The lines in black depict the previous simulation, while the lines in red illustrate this simulation with an increased $\mathrm{V}_{\mathrm{M} 3}$ (red box).

approximation of the experimental data, it does not provide a dose-response relationship. It has been documented in the literature that the higher the level of $\mathrm{IP}_{3}$, the greater the release of $\mathrm{Ca}^{2+}$ from the ER ${ }^{\text {[62] }}$. Taking the limitations of the Goldbeter model into account, this simulation reasonably resembles the $\mathrm{IP}_{3}$ sensitive $\mathrm{Ca}^{2+}$ release from the $\left[\mathrm{Ca}^{2+}\right]_{\mathrm{ER}}$ pool.

According to the results, $\mathrm{Ca}^{2+}$ released from the ER to the cytosol can effectively gate BK channels, and the main effect is to stop the spike train (Figure 6). These findings are consistent with reported experimental data. The $\mathrm{Ca}^{2+}$ released from ER stores, specifically through $\mathrm{IP}_{3} \mathrm{Rs}$ but not RyRs, produces pauses in the firing of spiny projection neurons due to the activation of BK and SK channels ${ }^{[63]}$. The author proposes two $\mathrm{Ca}^{2+}$ signaling pathways:

(1) action potential $\rightarrow$ VGCC $\rightarrow$ RyR $\rightarrow$ BK \& SK $\rightarrow$ sAHP (slow afterhyperpolarization); and

(2) $\mathrm{mGluR} / \mathrm{mAChR}$ (metabotropic glutamate receptors / muscarinic acetylcholine receptors) $\rightarrow \mathrm{IP}_{3} \rightarrow$ $\mathrm{IP}_{3} \mathrm{R} \rightarrow \mathrm{BK} \& \mathrm{SK} \rightarrow$ firing pause.

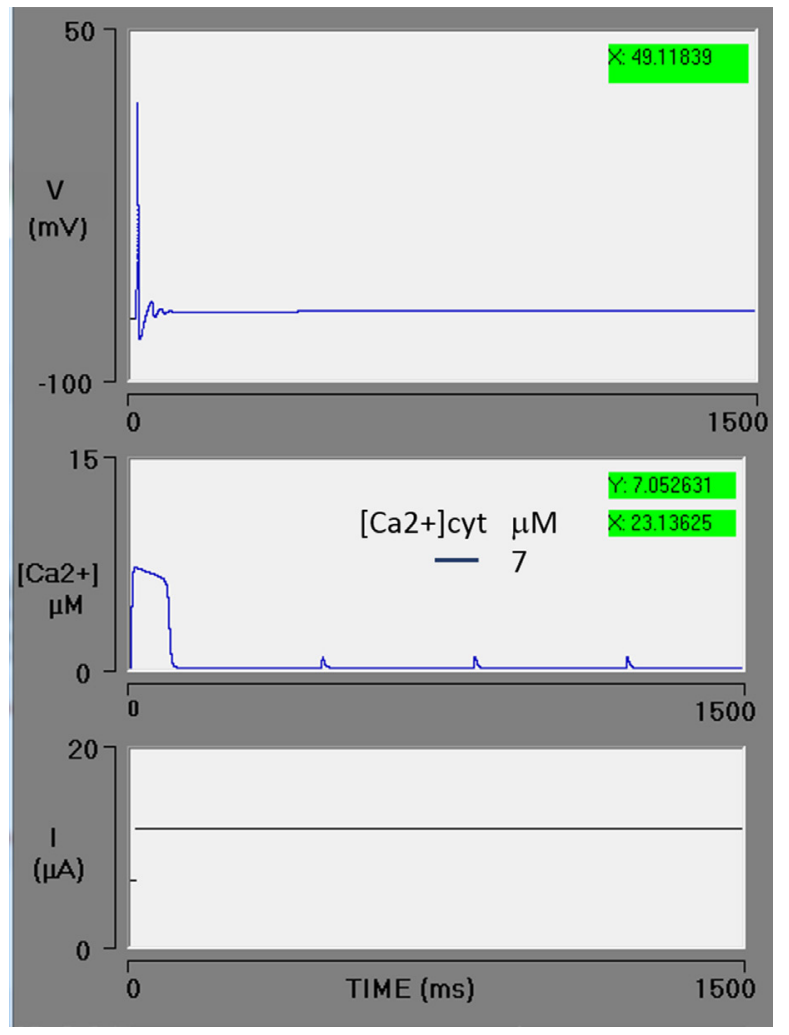

FIGURE 6. Spike train simulation with high efflux of $\mathrm{Ca}^{2+}$ from the endoplasmic reticulum (ER) pool. The maximum rate of $\mathrm{Ca}^{2+}$ efflux $\left(\mathrm{V}_{\mathrm{M} 3}\right)=700 \mu \mathrm{M} / \mathrm{s}$, resulting in a cytosolic $\mathrm{Ca}^{2+}$ transient increase with an amplitude of $7 \mu \mathrm{M}$. The greater level of cytosolic $\mathrm{Ca}^{2+}$ activated the BK channels, immediately stopping the spike train.

In the current contribution, a theoretical evaluation was made of the level of $\left[\mathrm{Ca}^{2+}\right]_{\mathrm{cyt}}$, mainly considering the interaction of $\mathrm{IP}_{3}$-Rs with BK channels. The find- 
ings support the possible existence of a microdomain. In places where the ER membrane and the cytoplasmic membrane are far apart, the diffusion and chelation will decrease the amplitude of the $\mathrm{Ca}^{2+}$ signal and this mechanism may not be activated. This depends, according to the results presented here, on the number of BK channels present in the membrane. The diffusion and chelation processes of $\mathrm{Ca}^{2+}$ are not contemplated in this model.

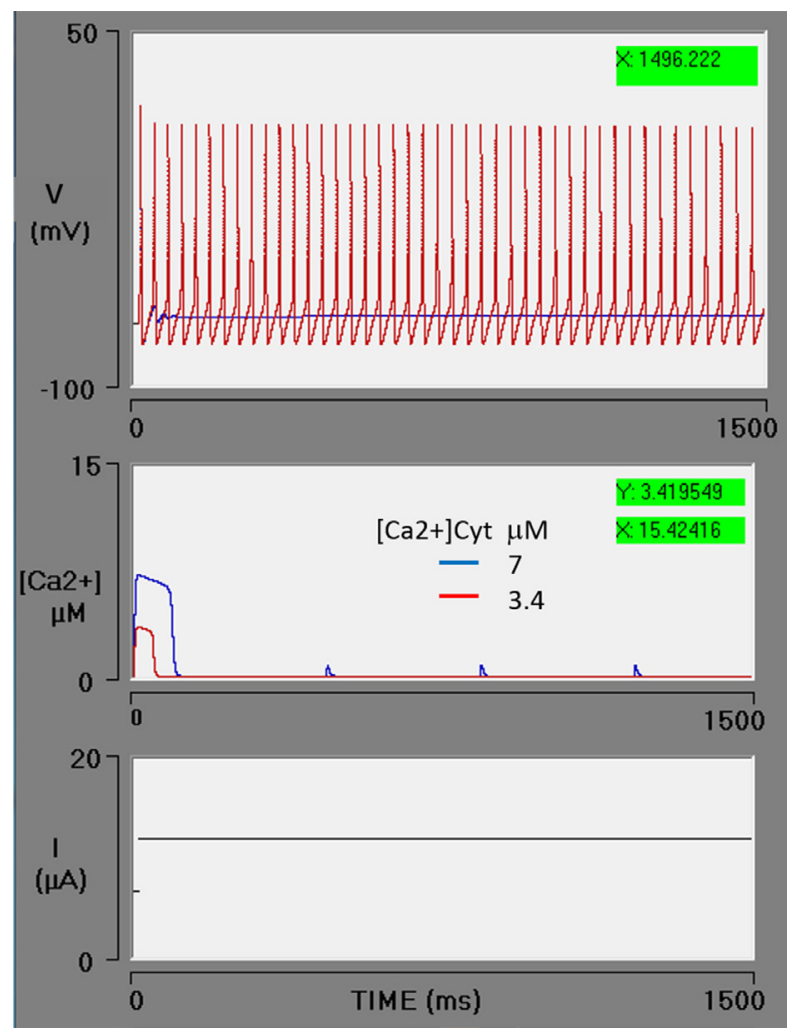

FIGURE 7. $\mathrm{Ca}^{2+}$ uptake from the cytosol by the SERCA pump. The action of the SERCA pump is increased by an increment in the $\mathrm{K}_{2}$ parameter (from 1 to $2 \mu \mathrm{M}$, being the threshold constant for pumping; red box).

The concentration of cytosolic calcium decreases from 7 to $3.4 \mu \mathrm{M}$. Consequently, cytosolic calcium is below the threshold required for the activation of the BK channels and the neuron has a sustained action potential train. The blue line portrays the previous simulation (Figure 6), using the same value of $\mathrm{V}_{\mathrm{M} 3}$ (blue box) in this simulation. The red line depicts the present simulation (with the SERCA pump set at a higher rate).
The effect of accelerating the action of the ATPase pump (SERCA) was explored under conditions of high $\mathrm{Ca}^{2+}$ efflux (the previous simulation). An increase in the $\mathrm{K}_{2}$ parameter (the threshold constant for pumping) from 1 to $2 \mu \mathrm{M}$ decreases the concentration of $\left[\mathrm{Ca}^{2+}\right]_{\mathrm{cyt}}$ from 7 to $3.4 \mu \mathrm{M}$. As can be appreciated, the action potential train is reversed and the neuron fires continuously during the simulated time (Figure 7).

Under physiological conditions, the PMCA pump and the SERCA pump are responsible for avoiding an excess concentration of $\left[\mathrm{Ca}^{2+}\right]_{\text {cyt }}$, which could be toxic to the cell ${ }^{[22]}{ }^{[49]}$. Such an excess concentration of $\mathrm{Ca}^{2+}$ would inhibit $\mathrm{IP}_{3}-\mathrm{R}^{[22]}$. Calcium oscillations have been demonstrated to move like waves with an amplitude in the order of $\mathrm{nM}{ }^{[21]}{ }^{[36]}$ and a range dependent on their diffusion and binding with chelating molecules ${ }^{[18]}$. These oscillations have been proposed as signals for various cellular processes, including synaptic plasticity, regulation of neurotransmission, cell differentiation, apoptosis, embryonic development, and secretion ${ }^{[21]}$. The abrupt influx of $\mathrm{Ca}^{2+}$ into the cell by voltage-gated calcium channels in the plasma membrane activates BK channels and triggers a change in action potential frequency ${ }^{[18]}$. The results of the present simulation show how an abrupt, focused increase in $\left[\mathrm{Ca}^{2+}\right]$ cyt from the endoplasmic reticulum store, very similar to those described as "spark", favors the activation of BK channels and produces a pause in the action potential train. This would imply that, under certain conditions, a mechanism capable of stopping neuronal signaling is activated.

\section{CONCLUSIONS}

A theoretical study of the $\mathrm{IP}_{3}-\mathrm{R} / \mathrm{BK}$ channel interaction was carried out by means of a simulator. Consequently, it was possible to modify the parameters to regulate the concentration of $\mathrm{Ca}^{2+}$ in the cytosol in order to monitor the effects. The variables considered are related to the flow of $\mathrm{Ca}^{2+}$ from cytosol: out of the cytosol to the ER (the SERCA pump) and to extra- 
cellular space (the PMCA pump), as well as into the cytosol from the ER (through the $\mathrm{IP}_{3}$-Rs) and from extracellular space (the VGCCs). Additionally, the conductance of the BK channel and the parameters of the Goldbeter model are included.

Some insights were provided into the general character of the $\mathrm{IP}_{3}-\mathrm{R} / \mathrm{BK}$ channel interaction. (1) The $\left[\mathrm{Ca}^{2+}\right]_{\mathrm{cyt}}$ concentration required to activate BK channels varies in accordance with the conductance of the channel. With a greater conductance, the concentration of $\mathrm{Ca}^{2+}$ necessary for activation is lower. (2) The BK channel is activated by an abrupt release of $\mathrm{Ca}^{2+}$ from the ER. This increase in $\mathrm{Ca}^{2+}$ is local and resembles spark. (3) The amplitude and duration of the abrupt efflux of $\mathrm{Ca}^{2+}$ from the ER depends on the difference in the concentration between the free $\left[\mathrm{Ca}^{2+}\right]_{\mathrm{cyt}}$ and the free $\left[\mathrm{Ca}^{2+}\right]_{\mathrm{ER}}$. The higher the concentration of the latter, the greater the amplitude and duration of the efflux. (4) A rise in the concentration of $\left[\mathrm{Ca}^{2+}\right]_{\mathrm{cyt}}$ increases the concentration of $\left[\mathrm{Ca}^{2+}\right]_{\text {cyt }}$ and favors the activation of BK channels. (5) An acceleration of the SERCA and/or PMCA pumps decreases the concentration of $\left[\mathrm{Ca}^{2+}\right]_{\mathrm{cyt}}$, thus reducing or avoiding the activation of BK channels. (6) A rise in $\left[\mathrm{Ca}^{2+}\right]_{\text {cyt }}$ activates the BK channels, leading to an immediate pause or stop of the spike train. This function will allow the neuron to generate a firing pattern in burts and under certain conditions be a possible mechanism for resetting or preventing sustained abnormal PA activities (7). The colocalization of the BK and $\mathrm{IP}_{3}-\mathrm{R}$ channels in a microdomain is a necessary condition for the manifestation of the following pathway in a neuron: $\mathrm{IP}_{3} \rightarrow \mathrm{IP}_{3}-\mathrm{R} \rightarrow \mathrm{Ca}^{2+} \rightarrow$ BK channels $\rightarrow$ pause (stop). This sequence is the regulatory mechanism (8) For neurons with a low $\mathrm{g}_{\mathrm{BK}}$, a high $\left[\mathrm{Ca}^{2+}\right]_{\mathrm{cyt}}$ concentration, and a greater difference between this parameter and free $\left[\mathrm{Ca}^{2+}\right]_{\mathrm{ER}}$ is necessary to activate BK channels. (9) In case of having an elevated level of $g_{\mathrm{BK}}$ conductance, neurons activate the BK channels more easily. The aforementioned theoretical results help to explain the experimental data of Clements et al. [63] and are in accordance with the proposal made by these authors about the existence of $\mathrm{Ca}^{2+}$ signaling pathways that mediate $\mathrm{BK}$ channel activation according to the level of $\left[\mathrm{Ca}^{2+}\right]_{\mathrm{ER}}$.

\section{AUTHOR CONTRIBUTIONS}

M.E.P.B. consultant in physiology and in charge of the simulated experiments. M.R.M. was responsible for programming the design of interfaces and figures. J.Q.P. supervised the union of the models and the bibliographic review. M.F.P.E. oversaw the programming and compilation of the simulators. A.R.L. consulting in neuroscience and programming, in charge of mathematical models and their numerical solution. All authors participated in the structural analysis, review, and correction of the work.

\section{ACKNOWLEDGMENTS}

The authors thank Bruce Allan Larsen and Laura Flores for proofreading the manuscript, and Dr. Jorge Flores-Hernández for useful comments. 


\section{REFERENCES}

[1] Sausbier U, Sausbier M, Sailer CA, Arntz C, Knaus HG, Neuhuber W, et al. $\mathrm{Ca}^{2+}$-activated $\mathrm{K}^{+}$channels of the BK-type in the mouse brain. Histochem Cell Biol [Internet]. 2005;125(6):725-41. Available from: https://doi.org/10.1007/s00418-005-0124-7

[2] Faber ESL, Sah P. Calcium-Activated Potassium Channels: Multiple Contributions to Neuronal Function. Neurosci [Internet]. 2003;9(3):181-94. Available from: https://doi.org/10.1177/1073858403009003011

[3] Meech RW. Intracellular calcium injection causes increased potassium conductance in Aplysia nerve cells. Comp Biochem Physiol Part A Physiol [Internet]. 1972;42(2):493-9. Available from: https://doi.org/10.1016/0300-9629(72)90128-4

[4] Latorre R, Castillo K, Carrasquel-Ursulaez W, Sepulveda RV, Gonzalez-Nilo F, Gonzalez C, et al. Molecular determinants of BK channel functional diversity and functioning. Physiol Rev [Internet]. 2017;97(1):39-87. Available from: https://doi.org/10.1152/physrev.00001.2016

[5] Kshatri AS, Gonzalez-Hernandez A, Giraldez T. Physiological Roles and Therapeutic Potential of $\mathrm{Ca}^{2+}$ Activated Potassium Channels in the Nervous System. Front Mol Neurosci [Internet]. 2018;11:1-18. Available from: https://doi.org/10.3389/fnmol.2018.00258

[6] Lee US, Cui J. BK channel activation: structural and functional insights. Trends Neurosci [Internet]. 2010;33(9):415-23. Available from: https://doi.org/10.1016/j.tins.2010.06.004

[7] Horrigan FT, Aldrich RW. Coupling between voltage sensor activation , $\mathrm{Ca}^{2+}$ binding and channel opening in large conductance (BK) potassium channels. J Gen Physiol [Internet]. 2002;120:267305. Available from: https://doi.org/10.1085/jgp.20028605

[8] Ha GE, Cheong E. Spike frequency adaptation in neurons of the central nervous system. Exp Neurobiol [Internet]. 2017;26(4):17985. Available from: https://doi.org/10.5607/en.2017.26.4.179

[9] Bock T, Stuart GJ. The Impact of BK Channels on Cellular Excitability Depends on their Subcellular Location. Front Cell Neurosci [Internet]. 2016;10:1-8. Available from: https://doi.org/10.3389/fncel.2016.00206

[10] Gu N, Vervaeke K, Storm JF. BK potassium channels facilitate highfrequency firing and cause early spike frequency adaptation in rat CA1 hippocampal pyramidal cells. J Physiol [Internet]. 2007;3:85982. Available from: https://doi.org/10.1113/jphysiol.2006.126367

[11] Berkefeld H, Fakler B, Schulte U. $\mathrm{Ca}^{2+}$-Activated $\mathrm{K}^{+}$Channels: From Protein Complexes to Function. Physiol Rev [Internet]. 2010;90(4):1437-59. Available from: https://doi.org/10.1152/physrev.00049.2009

[12] Misonou H, Menegola M, Buchwalder L, Park E, Meredith A, Rhodes $\mathrm{K}$, et al. Immunolocalization of the $\mathrm{Ca}^{2+}$-activated $\mathrm{K}^{+}$ channel Slo1 in axons and nerve terminals of mammalian brain and cultured neurons. J Comp Neurol [Internet]. 2006;496(3):289302. Available from: https://doi.org/10.1002/cne.20931

[13] Wang Z-W. Regulation of Synaptic Transmission by Presynaptic CaMKII and BK Channels. Mol Neurobiol [Internet]. 2008;38(2):153-66. Available from: https://doi.org/10.1007/s12035-008-8039-7
[14] Griguoli M, Sgritta M, Cherubini E. Presynaptic BK channels control transmitter release: physiological relevance and potential therapeutic implications. J Physiol [Internet]. 2016;13:3489-500. Available from: https://doi.org/10.1113/JP271841

[15] Bygrave FL, Benedetti A. What is the concentration of calcium ions in the endoplasmic reticulum? Cell Calcium [Internet]. 1996;19(6):547-51. Available from: https://doi.org/10.1016/s0143-4160(96)90064-0

[16] Berridge MJ. Calcium microdomains: Organization and function. Cell Calcium [Internet]. 2006;40(5-6):405-12. Available from: https://doi.org/10.1016/j.ceca.2006.09.002

[17] Dopico AM, Bukiya AN, Jaggar JH. Calcium- and voltage-gated BK channels in vascular smooth muscle. Pflügers Archiv [Internet] 2018;470(9):1271-89. Available from: https://doi.org/10.1007/s00424-018-2151-y

[18] Fakler B, Adelman JP. Control of KCa Channels by Calcium Nano/ Microdomains. Neuron [Internet]. 2008;59(6):873-81. Available from: https://doi.org/10.1016/i.neuron.2008.09.001

[19] Samtleben S, Jaepel J, Fecher C, Andreska T, Rehberg M, Blum R. Direct imaging of ER calcium with targeted-esterase induced dye loading (TED). J Vis Exp [Internet]. 2013;(75):1-17. Available from: https://doi.org/10.3791/50317

[20] Verkhratsky A. Physiology and Pathophysiology of the Calcium Store in the Endoplasmic Reticulum of Neurons. Physiol Rev [Internet]. 2005;85(1):201-79. Available from: https://doi.org/10.1152/physrev.00004.2004

[21] Karagas NE, Venkatachalam K. Roles for the Endoplasmic Reticulum in Regulation of Neuronal Calcium Homeostasis. Cells [Internet]. 2019;8(10):1232. Available from: https://doi.org/10.3390/cells8101232

[22] Foskett JK, White C, Cheung K-H, Mak D-OD. Inositol Trisphosphate Receptor $\mathrm{Ca}^{2+}$ Release Channels. Physiol Rev [Internet]. 2007;87(2):593-658. Available from: https://doi.org/10.1152/physrev.00035.2006

[23] Irie T, Trussell LO. Double-Nanodomain Coupling of Calcium Channels, Ryanodine Receptors, and BK Channels Controls the Generation of Burst Firing. Neuron [Internet]. 2017;96(4):856-870. e4. Available from: https://doi.org/10.1016/j.neuron.2017.10.014

[24] Wu Y, Whiteus C, Xu CS, Hayworth KJ, Weinberg RJ, Hess HF, et al. Contacts between the endoplasmic reticulum and other membranes in neurons. Proc Natl Acad Sci U S A [Internet]. 2017;114(24):E4859-67. Available from: https://doi.org/10.1073/pnas.1701078114

[25] Terasaki M, Shemesh T, Kasthuri N, Klemm RW, Hayworth KJ, Hand AR, et al. Stacked endoplasmic reticulum sheets are connected by helicoidal membrane motifs. Cell [Internet]. 2013;154(2):285-96. Available from: https://doi.org/10.1016/j.cell.2013.06.031

[26] Takahashi K, Wood RL. Subsurface cisterns in the Purkinje cells of cerebellum of Syrian hamster. Zeitschrift für Zellforsch und Mikroskopische Anat [Internet]. 1970;110(3):311-20. Available from: https://doi.org/10.1007/BF00321144 
[27] Pan NC, Bai YF, Yang Y, Hökfelt T, Xu ZQD. Activation of galanin receptor 2 stimulates large conductance $\mathrm{Ca}^{2+}$-dependent $\mathrm{K}^{+}(\mathrm{BK})$ channels through the $\mathrm{IP}_{3}$ pathway in human embryonic kidney (HEK293) cells. Biochem Biophys Res Commun [Internet]. 2014;446(1):316-21. Available from: https://doi.org/10.1016/j.bbrc.2014.02.110

[28] Mujica PE, González FG. Interaction between $\mathrm{IP}_{3}$ receptors and BK channels in arterial smooth muscle: Non-canonical $\mathrm{IP}_{3}$ signaling at work. J Gen Physiol [Internet]. 2011;137(5):473-7. Available from: https://doi.org/10.1085/igp.201110607

[29] Bootman MD, Collins TJ, Peppiatt CM, Prothero LS, MacKenzie L, De Smet P, et al. Calcium signalling - An overview. Semin Cell Dev Biol [Internet]. 2001;12(1):3-10. Available from: https://doi.org/10.1006/scdb.2000.0211

[30] Larkum ME, Watanabe S, Nakamura T, Lasser-Ross N, Ross WN. Synaptically Activated $\mathrm{Ca}^{2+}$ Waves in Layer 2/3 and Layer 5 Rat Neocortically Pyramidal Neurons. J Physiol [Internet]. 2003;549(2):471-88. Available from: https://doi.org/10.1113/jphysiol.2002.037614

[31] Ross WN. Understanding calcium waves and sparks in central neurons. Nat Rev Neuoscience [Internet]. 2015;13(3):157-68. Available from: https://doi.org/10.1038/nrn3168

[32] Goldbeter A, Dupont G, Berridge MJ. Minimal model for signalinduced $\mathrm{Ca}^{2+}$ oscillations and for their frequency encoding through protein phosphorylation. Proc Natl Acad Sci U S A [Internet]. 1990;87(4):1461-5. Available from: https://doi.org/10.1073/pnas.87.4.1461

[33] De Young GW, Keizer J. A single-pool inositol 1,4,5-trisphosphatereceptor-based model for agonist-stimulated oscillations in $\mathrm{Ca}^{2+}$ concentration. Proc Natl Acad Sci U S A [Internet]. 1992;89(20):9895-9. Available from: https://doi.org/10.1073/pnas.89.20.9895

[34] Li Y-X, Rinzel J. Equations for InsP ${ }_{3}$ Receptor-mediated $\left[\mathrm{Ca}^{2+}\right] \mathrm{i}$ Oscillations Derived from a Detailed Kinetic Model: A HodgkinHuxley Like Formalism. J Theor Biol [Internet]. 1994;166(4):46173. Available from: https://doi.org/10.1006/itbi.1994.1041

[35] Bezprozvanny I, Ehrlich BE. Inositol $(1,4,5)$-trisphosphate ( Insp $_{3}$ )gated Ca channels from cerebellum: Conduction properties for divalent cations and regulation by intraluminal calcium. J Gen Physiol [Internet]. 1994;104(5):821-56. Available from: https://doi.org/10.1085/jgp.104.5.821

[36] Keizer J, Li YX, Stojilkovic S, Rinzel J. Essay InsP $\mathrm{P}_{3}$-induced $\mathrm{Ca}^{2+}$ excitability of the endoplasmic reticulum. Mol Biol Cell [Internet]. 1995;6:945-51. Available from: https://doi.org/10.1091/mbc.6.8.945

[37] Tang Y, Stephenson JL, Othmer HG. Simplification and Analysis of Models of Calcium Dynamics Based on $\mathrm{IP}_{3}$-Sensitive Calcium Channel Kinetics. Biophys J [Internet]. 1996;70(1):246-63. Available from: https://doi.org/10.1016/S0006-3495(96)79567-X

[38] Sneyd J, Falcke M. Models of the inositol trisphosphate receptor. Prog Biophys Mol [Internet]. 2005;89(3):207-45. Available from: https://doi.org/10.1016/j.pbiomolbio.2004.11.001

[39] Kötter R. Neuroscience Databases: A Practical Guide. New York: Springer; 2003. $310 \mathrm{p}$.

[40] Hituri K, Linne M-L. Comparison of Models for IP3 Receptor Kinetics Using Stochastic Simulations. PLoS One [Internet]. 2013;8(4): e59618. Available from: https://doi.org/10.1371/journal.pone.0059618
[41] Edgerton JR, Reinhart PH. Distinct contributions of small and large conductance $\mathrm{Ca}^{2+}$ - activated $\mathrm{K}^{+}$channels to rat Purkinje neuron function. J Physiol [Internet]. 2003;548(1):53-69. Available from: https://doi.org/10.1113/iphysiol.2002.027854

[42] Blaustein MP, Golovina VA. Structural complexity and functional diversity of endoplasmic reticulum $\mathrm{Ca}^{2+}$ stores. Trends Neurosci [Internet]. 2001;24(10):602-8. Available from: https://doi.org/10.1016/s0166-2236(00)01891-9

[43] Sterratt D, Graham B, Gillies A, Willshaw D. Principles of Computational Modelling in Neuroscience. Cambridge: Cambridge University Press; 2011. 300p.

[44] Traub RD, Miles R. Neuronal Networks Hippocampus. Cambridge: Cambridge University Press; 1991. 281p.

[45] Hodgkin AL, Huxley AF. A quantitative description of membrane current and its application to conduction and excitation in Nerve. J Physiol [Internet]. 1952;117(4):500-44. Available from: https://doi.org/10.1113/iphysiol.1952.sp004764.

[46] McCarron JG, Chalmers S, Bradley KN, MacMillan D, Muir TC. Ca ${ }^{2}$ microdomains in smooth muscle. Cell Calcium [Internet]. 2006;40(5-6):461-93. Available from: https://doi.org/10.1016/j.ceca.2006.08.010

[47] Blackwell KT. Approaches and tools for modeling signaling pathways and calcium dynamics in neurons. J Neurosci Methods [Internet]. 2013;220(2):131-140. Available from: https://doi.org/10.1016/i.jneumeth.2013.05.008

[48] Chen-Engerer HJ, Hartmann J, Karl RM, Yang J, Feske S, Konnerth A. Two types of functionally distinct $\mathrm{Ca}^{2+}$ stores in hippocampal neurons. Nat Commun [Internet]. 2019;10(1):1-8. Available from: https://doi.org/10.1038/s41467-019-11207-8

[49] Dupont $\mathrm{G}$, Goldbeter A. One-pool model for $\mathrm{Ca}^{2+}$ oscillations involving $\mathrm{Ca}^{2+}$ and inositol 1,4,5-triphosphate as co-agonists for $\mathrm{Ca}^{2+}$ release. Cell Calcium [Internet]. 1993;14(4):311-22. Available from: https://doi.org/10.1016/0143-4160(93)90052-8

[50] Blackwell KT. Modeling calcium concentration and biochemical reactions. Brains, Minds, and Media [Internet]. 2005;1:1-27. Available from: https://www.brains-minds-media.org/archive/224

[51] Zill DG. Ecuaciones diferenciales con aplicaciones. México: Grupo Editorial Iberoamérica; 1988. 516p. Spanish.

[52] Constantinides A. Applied Numerical Methods with Personal Computers. New York, USA: McGraw-Hill International Editions; 1987. 626p.

[53] Foskett JK, White C, Cheung K-H, Mak D-OD. Inositol Trisphosphate Receptor $\mathrm{Ca}^{2+}$ release channels. Physiol Rev [Internet]. 2007;87(2):593-658. Available from: https://doi.org/10.1152/physrev.00035.2006

[54] Khodakhah K, Ogden D. Fast activation and inactivation of inositol trisphosphate evoked $\mathrm{Ca}^{2+}$ release in rat cerebellar Purkinje neurones. J Physiol [Internet]. 1995;487(2):343-58. Available from: https://doi.org/10.1113/jphysiol.1995.sp020884

[55] Cheng H, Lederer WJ. Calcium Sparks. Physiol Rev [Internet]. 2008;88(4):1491-545. Available from: https://doi.org/10.1152/physrev.00030.2007

[56] Naraghi M, Neher E. Linearized Buffered $\mathrm{Ca}^{2+}$ Diffusion in Microdomains and Its Implications for Calculation of $\left[\mathrm{Ca}^{2+}\right]$ at the Mouth of a Calcium Channel. J Neurosci [Internet]. Available from: 1997;17(18):6961-73. Available from: https://doi.org/10.1523/JNEUROSCI.17-18-06961.1997 
[57] Rizzuto R, Pozzan T. Microdomains of Intracellular $\mathrm{Ca}^{2+}$ : Molecular Determinants and Functional Consequences. Physiol Rev [Internet]. 2006;86(1):369-408. Available from: https://doi.org/10.1152/physrev.00004.2005

[58] Weaver AK, Olsen ML, McFerrin MB, Sontheimer H. BK Channels Are Linked to Inositol 1,4,5-Triphosphate Receptors via Lipid Rafts: A novel mechanism for coupling $\left[\mathrm{Ca}^{2+}\right]_{\mathrm{i}}$ to ion channel activation. $\mathrm{J}$ Biol Chem [Internet]. 2007;282(43):31558-68. Available from: https://doi.org/10.1074/jbc.M702866200

[59] Koch C, Segev I. Methods in Neuronal Modeling. Cambridge: The MIT Press; 1999. 671p.

[60] Berkefeld H, Fakler B. Repolarizing Responses of $\mathrm{BK}_{\mathrm{Ca}}$-Cav Complexes Are Distinctly Shaped by Their Cav Subunits. J Neurosci [Internet]. 2008;28(33):8238-45. Available from: https://doi.org/10.1523/JNEUROSCl.2274-08.2008
[61] Hou P, Xiao F, Liu H, Yuchi M, Zhang G, Wu Y, et al. Extrapolating microdomain $\mathrm{Ca}^{2+}$ dynamics using BK channels as a $\mathrm{Ca}^{2+}$ sensor. Sci Rep [Internet]. 2016;6:17343. Available from: https://doi.org/10.1038/srep17343

[62] Meyer T, Stryer L. Molecular model for receptor-stimulated calcium spiking. Proc Natl Acad Sci U S A [Internet]. 1988;85(14):5051-5. Available from: https://doi.org/10.1073/pnas.85.14.5051

[63] Clements MA, Swapna I, Morikawa H. Inositol 1,4,5-Triphosphate Drives Glutamatergic and Cholinergic Inhibition Selectively in Spiny Projection Neurons in the Striatum. J Neurosci [Internet]. 2013;33(6):2697-708. Available from: https://doi.org/10.1523/JNEUROSCl.4759-12.2013 